\title{
漢字認知に伴う形態レベルと意味レベルにおける プライミング効果:事象関連電位（ERP）による研究
}

\author{
北海道大学大学院教育学研究科 \\ 姚鵬鵬・諸冨隆 \\ 札幌学院大学社会情報学部 \\ 沖田 庸嵩
}

\section{Kanji Recognition and Semantic Priming \\ At Morphological and Semantic Levels: An Event-Related Brain Potential Study}

\author{
Peng-peng Yao, Takashi MorotomI \\ Graduate School of Education, Hokkaido University \\ Sapporo, Japan, 060-0811 \\ Tsunetaka OKITA \\ Faculty of Social Information \\ Sapporo Gaukuin University \\ Ebetsu, Hokkaido, Japan, 069-8555
}

Stolz \& Besner (1998) reported that there are two possible loci, morphological (i. e., letter and word) and semantic levels, for semantic priming in the interactive activation framework. To investigate the relation between levels of processing in Kanji recognition and the loci where the semantic priming occurs, event-related brain potentials (ERPs) to Kanji characters were recorded in two task conditions of semantic matching and non-task. The stimuli were presented in AAAAABAA form (habituation paradigm), and the repetition Kanji A and test Kanji $B$ were semantically related, unrelated, or identical. In the non-task condition, the semantic priming effect was observed in a positive wave with a 200-ms peak latency, P200 (P2); the recovery of P200 amplitude was reduced for the semantically related test Kanji characters, compared with the unrelated ones. In the semantic matching task, where the subjects were required to decide whether or not the repetition and test Kanji characters were semantically related, the priming effect was obtained as the attenuation of the later negative wave N310 (corresponding to N400) for the related test Kanji, instead of P200. The P200 priming effect was interpreted as the semantically related response at the morphological level, which was due to semantic-level activation feeding back to the corresponding morphological-level representation, whereas the N310 effect as a reflection of the semanticlevel activation of the semantic associates with the preceding Kanji. The task dependency of semantic priming levels indicated the top-down control in Kanji recognition processes.

Key words: Kanji recognition, semantic priming, interactive activation model, P200, N310

2000.4.10 受稿, 2000.8.24 受理 
【要 約】 Stolz \& Besner（1998）は，意味プライミング効果が相互活性化モデルの形態（すなわち 文字と単語）レベルと意味レベルの 2 力所で生じうると報告した。漢字認知の処理レベル間の関係掠よ び意味プライミング効果が生じる過程を検討するため, 意味関連性判断課題と無課題条件で事象関連電 位を記録した。慣れパラダイムに従い，反復刺激（A）とテスト刺激（B）となる漢字を1文字づつAA AAABAAのような順序で提示し，反復刺激とテスト刺激が意味的に関連する試行，意味的に関連しな い試行，全く同じ試行を設けた。無課題条件では，意味プライミング効果は刺激呈示後 $200 \mathrm{~ms}$ に頂点潜 時を持つ陽性成分P200（P2）において観察され，意味関連試行ではテスト刺激に対する振幅回復量が 意味非関連試行に比べて小さかった。意味関連性判断課題では, 被験者は反復刺激とテスト刺激の意味 関連性について判断が要請された，プライミング効果はP200成分より遅い陰性成分N310（N400に相当） で観察され，意味関連テスト刺激に対するN310は意味非関連に比べて小さかった．P200におけるプラ イミング効果は形態レベルにおける意味関連応答を示し, 意味レベルから形態レベルへの活性化フィー ドバックによって生じたと解釈された。他方，N310プライミング効果は意味レベルにおける意味関連 表象の活性化と理解された。意味応答レベルの課題依存性は漢字認知過程へのトップダウン制御を示唆 した。

日常生活において，新聞や本などの書き言葉の 意味は瞬時に読み取ることができる。この読語の 高速処理については，文字レベルから文章レベル の認知にかかわる広範な領域で多数の検討がなさ れてきた。その中でも意味抽出の根幹をなす単語 レベルの認知研究はロゴジェン・モデル（Morton, 1964）や相互活性化モデル（たとえば, McClelland, 1987; McClelland \& Rumelhart, 1981) などを産み出し, 議論の中核となってきた。ここ で問題となるのは, そうしたモデル構築が主とし て英単語を刺激とした実験結果に基づく点である. アルファベットとは異なる漢字表記のような単語 認知も同様のモデルで説明できるのであろうか. できるとすれば，そのモデルの枠組みでどの処理 過程に漢字表記の単語認知に特異性があるのか.

本論文では, 漢字表記の単語認知もアルファベッ ト表記語と類似のモデルで説明しうるという考え （Taft, 1991）に従い，相互活性化モデル（Stolz \& Besner, 1998）の枠組みで漢字表記語の処理特性 を探った。日本語で使用される漢字には，表音 (単音) 文字であるアルファベット表記語とは異 なる特徵がある。漢字は一字一字が意味を表して いるという点で表意文字であり，一文字で 1 単語 を表現しうるということで表語文字といえる(御 領，1987,p.14-18)。漢字は音韻的に分離できな い,一つの漢字は複数の発音に対応する特徵を持っ ている (Wydell, Patterson, Humphreys, 1993). さ らに，漢字の意味情報には音韻情報を介さず形態
情報から直接アクセスしうる特徵もある（たとえ ば, Feldman \& Turvey, 1980; 御領, 1987; Kimura, 1984; Sasanuma, 1975; Shimamura, 1987).

\section{意味プライミングと相互活性化モデル}

意味プライミングは, 視覚単語認知の多くの研 究で使用されてきたパラダイムの一つである，先 行するプライム語が意味的に関連すると, 無関連 な場合に比べ, 後続のテスト語の認知処理が促進 する（たとえば, Meyer \& Schvaneveldt, 1971）. この「意味プライミング効果」は読語過程におけ る意味抽出の促進作用を示すとともに，自動活性 化拡散モデルを産み出し, その後の多くの研究に 影響を与えた。自動活性化拡散モデルに従うと， プライム語の提示はその意味表象を活性化すると ともに，その活性化が意味関連の表象（ロゴジェ ン）にも自動的に拡散する。この活性化拡散が意 味関連語の処理を促進する（たとえば, Collins \& Loftus, 1975; Morton, 1969; Neely, 1977, 1991). し かし, 近年, プライム語の処理内容がプライミン グ効果に影響するという知見がある。たとえば, プライム語に対し文字探索を行わせると，テスト 語のプライミング効果は激減してしまった（たと えば, Friedrich, Henik, \& Tzelgov, 1991; Stolz \& Besner, 1996; 1998)。この知見は，プライム語の 処理内容が意味レベル内の, あるいは語彙レベル と意味レベルの表象間の活性化拡散を阻止するこ とを示しており，活性化拡散の自動性を仮定する 
モデルではその説明が難しくなってきた.

他方，McClellandら（たとえば，McClelland, 1987; McClelland \& Rumelhart, 1981; Rumelhart \& McClelland, 1982）が提唱した相互活性化（interactive activation) モデルでは，意味プライミング 効果それ自体を説明しがたいという指摘がある (たとえば，Taft, 1991)。このモデルでは，視覚 的特徵から文字パタンを統合する文字レベル (letter level), 単語の全体表象を賦活する単語レ ベル（すなわち，意味情報を持たない語彙レベル）， 単語の意味をアクセスする意味的レベルが想定さ れる。単語が視覚的に提示されると，低次ユニッ 卜群の活性化が高次ユニット群の処理に影響する。 高次ユニット群内で活性化が進むと, 低次ユニッ ト群で実行中の処理にフィードバック情報を与え る.こうしてレべル間には興奮性関係があるのに 対し，各レベル内では表象間で競合的な関係が想 定されている（McClelland, 1987）。意味レベルで いえば，入力語に対する意味を特定するうえで, 紛らわしい候補（意味表象）の活性化を抑制し， 最も適切な意味表象の活性化が最大となるように する。この抑制的な競合関係は，意味プライミン グを打ち消すような作用をもっている，意味プラ イミング効果を説明してきた興奮性の活性化拡散 とは相容れない考えである。

Stolz \& Besner（1996, 1998）は上記の相互活性 化モデルを継承しつつ, 意味プライミング効果を その枠組みで説明できるように，レベル間で関連 項目への活性化拡散を想定した。すなわち, 単語 レベルからのフィードフォワード（ボトムアップ） 経路を通した活性化入力によって, 意味レベルで は入力語対応表象のみならず，その意味関連表象 も活性化する。ささらに，このレベル間の拡散的な 活性化に加えて，レベル内の競合表象に対する抑 制も部分的と仮定した。この仮定により, 最も適 切な意味表象の特定を可能にするとともに, 意味 関連表象に残る活性化でプライミング効果を説明 した。

この二つの仮定を加えたうえで, Stolz \& Besner (1996, 1998) は, 意味プライミング効果 が相互活性化モデルの 2 力所で生じる可能性を示 した。ひとつは，上記のように，単語レベルから
意味レベルへの活性化搬送経路で生じる。たとえ ば，プライム語として「ネコ」という単語が提示 されると，文字レベルに続く単語レベルで，レベ ル内競合により，「ネコ」表象の活性化が候補の 中で最大となる，次に，この単語レベルの活性化 は意味レベルで「ネコ」とともに「イヌ」や「ネ ズミ」などの意味関連表象にも拡散的な活性化を もたらす。この意味レベルでも競合が生じ，「ネ コ」の活性化が最大となるが, 意味関連表象の活 性化も部分的に残る。この活性化の残存状態でテ スト語として「イヌ」が提示されると, 認知に必 要な活性化入力は少なくてすむ．この省力化がプ ライミング効果を産み出す基盤となる。残る一つ は，意味レベルから単語レベルへの活性化搬送 (フィードバック）経路で生じる，上記の例でい うと，意味レベルに扔ける「ネコ」および「イ邓」・ 「ネズミ」など関連表象の活性化は単語レベルの 表象にフィードバックされ，対応する表象を活性 化する。この活性化状態で「イ邓」がテスト語と して提示されると, 非関連語が先行するような場 合に比べて，すでに活性化している分だけ，単語 の特定に必要な文字レベルからの活性化情報は少 なくてすむ.すなわち，意味プライミング効果が 単語レベルで生じる第二の基盤がここにある.

このような相互活性化モデルで, Stolz \& Besner（1996, 1998）はプライム語の文字探索課 題が意味プライミング効果に及ぼす影響を次のよ うに説明する．プライム語の文字探索が要請され ると，プライム語の文字を 1 字ずつ意識的に（顕 在的に）同定していく必要がある。これに対し， 通常の意味プライミング課題では，プライム語は 単に黙読するだけであり，文字同定は潜在的な過 程で実行される。この二つを比べると，前者はプ ライム語の文字探索を容易に遂行させるため, 単 語レベルからのフィードバック経路を介した支援 を得て，文字レベルの活性化を高める必要がある。 ここで, 活性化の全容量に限界があると仮定し (Anderson, 1976, 1983), 活性化容量の大半が文 字レベルで消費されてしまうとすれば，意味レべ ルで活性化はほとんど生じないことになる。すな わち, プライム語の文字探索で, 単語レベルから 意味レベルへの活性化フィードフォワード経路が 
阻止され，意味プライミング効果が減弱ないし消 滅する，通常の意味プライミング課題では，文字 レベルで活性化容量をそれほど消費しないので, 意味レベル（さらに，単語レベル）で十分な活性 化が生じ, 意味プライミング効果を産み出すこと になる。

本研究では, 一文字で単語の特徵を持つ漢字を 刺激として使用した（たとえば，犬，桃)。従っ て, Stolz \& Besner（1998）の相互活性化モデル における文字レベルと単語レベルに対応づけるの は難しい。ここでは両レベルをまとめて形態レベ ルとし, 意味レベルと対比させて漢字の処理特性 を検討した。

\section{事象関連電位}

本研究では, 意味プライミング効果が生じるレ ベルを探る指標として時間分解能が優れた事象関 連脳電位（ERP）を採用し，以下に述べるような 単語認知処理に関与する一連の成分で分析を試み た。まず，形態レベルの視知覚処理にかかわる電 位として前頭-中心優勢な陽性成分（潜時150-200 ms，ここではP2 と呼ぶ）がある。 Shimoyama, Morita, Uemura, Kojima, Nakamura, Nishizawa, Yokoyama, Ryu, Murayama, \& Uchizono (1992) は漢字に惹起されるP2が線画より大きいことを 明らかにした. Schendan, Ganis, \& Kutas（1998） も類似の成分を見い出し, 単語や顔のような過学 習された刺激に対する注意の定位機能に関わり， 紡錘状回に発生源をもつ電位と示唆している。さ らに, Yao \& Morotomi（2000）は，P 2 成分が不 慣れな外国語より熟知性の高い母語で文字の微妙 な形態的変化に鋭敏に応ずることを明らかにして いる.

意味レベルの処理にかかわる電位としては N400成分が知られている。このN400は, 最初, 先行文脈から意味的に逸脱した文末の単語に対し て見い出されたが (Kutas \& Hillyard, 1980)，そ の後, プライム語とテスト語の対提示といった事 態でも惹起されることがわかってきた。たとえば, 「机-医者」に比べ，「看護婦-医者」のような意味 関連性の高いプライムが先行すると, テスト語の 「医者」に惹起されるN400は意味プライミングを
反映して減衰する（たとえば, Bentin, McCarthy, \& Wood, 1985).

本研究では, さらに, 刺激提示に応ずる認知活 動を全般的にとらえるため, 単語の処理レベルに 特異に応答する成分のほか， N400に後続して惹 起され，刺激評価時間や注意分割の指標となるP 3 成分なども分析対象とした。

\section{慣れパラダイム}

本実験では，ERPで意味プライミング効果を生 じるレベルを検索するため，プライム刺激とテス 卜刺激を対提示する通常の事態ではなく, 慣れパ ラダイムを適用し，反復（プライム）刺激Aとテ スト刺激BをAAAAABAAのような系列で提示し た。また，反復語とテスト語が意味的に関連性の 高い系列（たとえば，犬と猫），意味的に関連性 の低い系列 (たとえば，桃と猫），そして反復語・ テスト語とも同じ漢字を提示する系列（たとえば, 猫）を設けた. 被験者の課題としては, 反復語と テスト語が意味的に関連するか否か判断を要請す る条件と, 単に提示される語を黙読する無課題条 件を設定した。プライム語が反復提示される慣れ パラダイムの採用で, 意味関連性判断課題（以下， 単に, 意味判断課題) と無課題の両条件間の違い がより明瞭となると考えた。無課題条件では，提 示される漢字 1 文字づつをただ黙読するのみであ るが, 各系列で最初の漢字は異なるので, 自動的 に意味抽出機能が働き, 意味レベルの活性化があ る程度は生じる可能性がある。そうした意味レベ ルの活性化がたとえ生じたとしても，無課題状態 では反復提示で減弱するだろうと考えた。他方, 意味判断課題では, 効率良く課題を遂行するため に, 反復提示に対しても意味レベルの活性化を (意図的に) 維持しておく必要がある。こうした 条件間の活性化レベルの対比は, 意味プライミン グ効果が生ずるレベルに違いをもたらすものと期 待した。

\section{目的}

表意（表語）文字である漢字は形態（文字）レ ベルでどのような意味関連応答を示すのか, これ が本研究の根本となる興味である。相互活性化モ 
デル（Stolz \& Besner, 1996, 1998）に従えば，意 味レベルからのフィードバックにより, 形態レベ ルにおいても意味関連表象に活性化が生じ, 後続 の意味関連語入力に対する形態レベルの処理効率 を高める。本研究の第一の目的は，形態レベルに おける意味関連応答をテスト刺激に惹起された ERP-P2成分の意味プライミング効果で探ること であった．第二の目的は, 意味判断課題でのみ生 ずると予測される意味レベルにおけるプライミン グ効果をN400で捉え, 形態レベルと意味レベル の処理の関係を探ることであった。

\section{方法}

被験者 視力正常（矯正を含む）な大学生・大 学院生24名が, 12名づつに別れて意味判断課題条 件 (平均年齢23.1歳) と無課題条件 (平均年齢 23.6 歳)で実験を受けた。全員右手利きであった。

刺激 各試行の刺激系列は $8 ， 9$ ，または 10 刺 激で構成し，ビデオモニ夕の中央に提示されてい る凝視点 $(* * * * * *)$ が消えた直後, 同じ中央の位 置に漢字 1 文字を持続時間 $100 \mathrm{~ms}$, 刺激間隔 (ISI） $1500 \mathrm{~ms}$ で次々と提示した。テスト刺激は 同一文字の反復提示中の 6 番目， 7 番目，または 8 番目の位置に挿入した。この 3 位置の提示は等 確率とした。文字刺激は白色の背景に黑色で提示 した. Table 1 で示すように, 各系列の最初の刺 激は「慣れ（H 1)」，5番目の刺激は「テスト前 (PT)」, テスト刺激後の反復刺激を「脱慣れ（D 1)」 と名付けた。

慣れ刺激とテスト刺激の意味関連性を操作して, 試行で 3 条件を設けた。意味関連試行では慣れ刺 激とテスト刺激が意味関連性の高い漢字28対, 意 味非関連試行では意味関連性の低い漢字28対を使 用し, 統制試行では漢字28字のみで, 同じ漢字を 反復・テスト刺激として提示した。これらの刺激 は小川（1972）を参考に, 色・感覚・木・気象・ 果物などのカテゴリに所属する一文字の漢字を使 用した。

課題条件 意味判断課題では, 反復刺激とテス 卜刺激が意味的に関連する場合（意味関連試行） および同じ漢字がその刺激系列を通して反復提示 される場合 (統制試行) には左側のボタン, 反復
Table 1 Examples of Kanji characters in semanticallyrelated, semantically-unrelated, and control trails

\begin{tabular}{cccc}
\hline \multirow{2}{*}{ Position } & \multicolumn{3}{c}{ Trail } \\
\cline { 2 - 4 } & $\mathrm{R}$ & $\mathrm{UR}$ & $\mathrm{C}$ \\
\hline $\mathrm{H} 1$ & 桃 & 鴉 & 席 \\
H 2 & 桃 & 鴉 & 席 \\
H 3 & 桃 & 鴉 & 席 \\
H 4 & 桃 & 鴉 & 席 \\
PT & 桃 & 鴉 & 席 \\
T & 梨 & 機 & 席 \\
D 1 & 桃 & 鴉 & 席 \\
D 2 & 桃 & 鴉 & 席 \\
\hline
\end{tabular}

Note.

$\mathrm{R}$, semantically-related

UR, semantically-unrelated

C, control

H $1-\mathrm{H} 4$, positions 1 to 4 of habituation

PT, pretest

$T$, test

D 1 -D 2 , positions 1 to 2 of dishabituation

刺激とテスト刺激が意味的に関連しない場合（意 味非関連試行）には右側のボタンを, 各刺激系列 提示終了後, 押すように教示した. 無課題条件で は，そうしたボタン押し反応を要請せず，ただ提 示される文字を見ている（黙読する）ように教示 した.

手続き 電極装着後, 被験者は防音シールド室 内に入り, CRT画面に対面して安楽椅子に座った. 被験者には凝視点 $(* * * * * *)$ の位置に視点を定め, 文字刺激提示中は体動や瞬きをできるだけ避ける ように教示した。なお，本試行に先立って，被験 者が課題に慣れるまで練習を行った。

その後, 各被験者は意味関連・意味非関連・統 制の各試行を無作為な順序で28回づつ受けた。各 試行後には短い休憩を設けた。

実験終了後, 無課題条件を受けた被験者には, 反復・テスト刺激の意味的関連性に気づいたかど うか尋ねた。

脳波の記録および処理 脳波は銀・塩化銀血電 極を用い, 両耳垂結合を基準電極として, 国際式 
10-20法による $\mathrm{Fz} \cdot \mathrm{Cz} \cdot \mathrm{Pz} \cdot \mathrm{F} 3 \cdot \mathrm{F} 4 \cdot \mathrm{P} 3 \cdot \mathrm{P} 4 \cdot$ $\mathrm{O} 1 \cdot \mathrm{O} 2$, およびウェルニッケ相当野（WL: C 3 T 5 中間）とその反側野 (WR: C 4-T 6 中間) の11 力所から基準導出した。 さらに, 左目眉の上約 1 $\mathrm{cm}$ と左目尻の耳側約 $1 \mathrm{~cm}$ から眼球運動を監視し た。接地電極は前額に装着した。带域遮断周波数 は0.05-30 Hz，サンプリングは200 Hzであった。

各系列位置 $(\mathrm{H} 1 \cdot \mathrm{PT} \cdot \mathrm{T} \cdot \mathrm{D} 1)$ の刺激前 200 $\mathrm{ms}$ から刺激後 $1200 \mathrm{~ms}$, 計 $1400 \mathrm{~ms}$ 間をERP算出の 分析対象とした。各被験者のERPは, 試行（意味 関連・意味非関連 - 統制), 系列位置 (H 1 P P · $\mathrm{T} \cdot \mathrm{D} 1)$, 電極部位別に加算平均により算出した。 誤反応，瞬き，アーティファクトなどが混入した 試行は加算平均処理から除外した。結果として, 各被験者における波形算出の加算数は18-28回で あった。

ERP各成分の振幅は, 刺激提示前 $100 \mathrm{~ms}$ 間の平 均電位を基線とし, 刺激提示後180-240 ms間 ( $\mathrm{P}$ 200)，275-335 ms間（N310），350-450 ms間（P400）, 450-750 ms 間（N600）の各平均電位を求めて定量 化した。これらの平均電位に基づき, 試行・系列 位置・電極部位の効果を評価するため, 課題条件 別に被験者内要因配置の分散分析を行った。タイ プIの誤差に対してはGreenhouse-Geisserの修正 法を用いた。下位検定はTukey法を使用した。有 意水準はいずれも5\%とした。

\section{結 果}

\section{課題成績}

意味判断課題条件では, 意味関連・意味非関連・ 統制の各試行における課題遂行の正反応率は $98 \%$ 以上で，各試行間に有意差はなかった。

\section{ERPs}

Fig. 1 は, 意味判断課題条件と無課題条件の正 中線上に拈ける意味関連・意味非関連・統制試行 に対する被験者間総平均ERP波形である。両課題 条件のすべての試行の慣れ刺激の 1 回目（H 1) 提示, 意味関連と非関連試行のテスト刺激に対し, 頂点潜時約 $200 \mathrm{~ms}$ をつ大きく発達した陽性頂点 (P200）が見られる。続いて，そうした刺激には， 刺激提示後 $305 \mathrm{~ms}$ 付近に㓌性頂点（N310）が観 察される。さらに，テスト刺激には課題条件にか
かわらず, 刺激後 $400 \mathrm{~ms}$ 近傍に中心-頭頂部優勢 な大きな陽性電位（P400）が惹起されている.

Fig. 2 は, 各課題条件の意味関連性（意味プラ イミング）効果をテスト刺激の波形上で見るため に, 意味非関連試行から意味関連試行の波形を減 算して求めた全導出部位の引算波形である。両課 題条件を通して最も早く見られる効果は，無課題 条件に扔ける刺激後 $200 \mathrm{~ms}$ 近傍の中心-頭頂及び 右側優勢な陽性方向への振れであり, P200が意 味非関連テス卜刺激に対し意味関連よりも大きい ことを示している.この無課題条件では, その後 $800 \mathrm{~ms}$ 辺りまで, 波形に目立った振れは見当たら ない。意味判断課題条件で最初に認められる意味 関連性効果は, 刺激後 $310 \mathrm{~ms}$ 近傍に, 特に正中頭 頂部 $(\mathrm{Pz})$ と右側の頭頂（P 4 ）・ウェルニッケ 相当部位（WR）で尖鋭な陰性頂点をもつ振れが あり, 意味関連テスト刺激の $\mathrm{N} 310 か ゙$ 意味非関連 試行に比べささいことに对応している。 さらに， 意味判断課題では, 刺激後 $400 \mathrm{~ms}$ 付近に除性頂点 があり, それはP 400 の出現潜時带に相当する。 意味関連試行のP 400 が意味非関連よりも大きい ことを示している.加えて，さららに大きく緩徐な 除性の振れがある。Fig. 1 をみると, 意味非関連 テスト刺激のERPが意味関連よりもP400から早く 基線方向に復帰する傾向にあり, 潜時 $600 \mathrm{~ms}$ 前後 に緩やかな陰性方向への膨らみが発達している。

この意味非関連テスト刺激に発達する緩徐な陰性 電位を, Fig. 2 の引算波形に $600 \mathrm{~ms}$ 近傍の陰性波 が反映しているようにみえる。ここでは，この陰 性波をN600として分析した。

\section{P200}

Fig. 3 上段は意味判断課題条件と無課題条件で 正中線上の効果を示す $\mathrm{Cz}$ におけるP 200 振幅であ る. 課題条件別に, 正中線上で試行（意味関連 意味非関連・統制） $\times$ 系列位置 $(\mathrm{H} 1 \cdot \mathrm{PT} \cdot \mathrm{T} \cdot \mathrm{D}$ 1) $\times$ 電極部位 $(\mathrm{Fz} \cdot \mathrm{Cz} \cdot \mathrm{Pz})$ の 3 要因分散分析 を行った結果, 意味判断課題条件で試行 $\times$ 位置の 交互作用が有意であった $(F(6,66)=3.0, p<.05)$. 下位検定の結果，全試行において，同一刺激の反 復提示による慣れを反映して，H１位置に比べPT 位置でP200減衰を認めた。また, 意味関連と非 関連試行では, PT後のテスト刺激でP200振幅の 


\section{Semantic matching task}

CONTROL
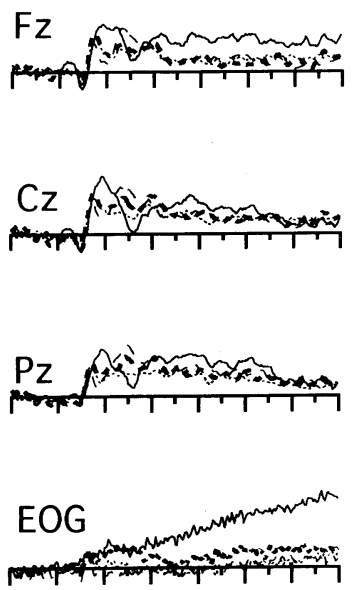

\section{Non-task}

CONTROL
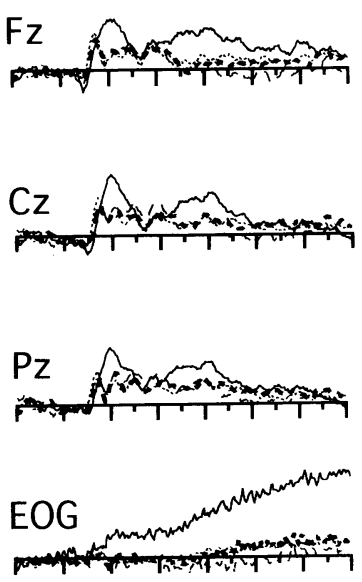

UNRELATED
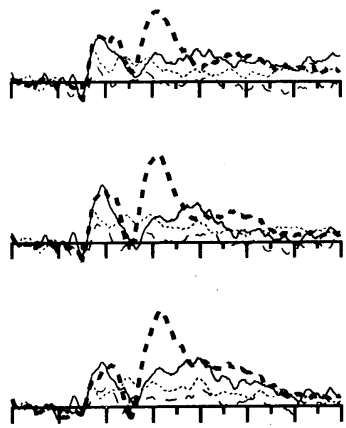

UNRELATED
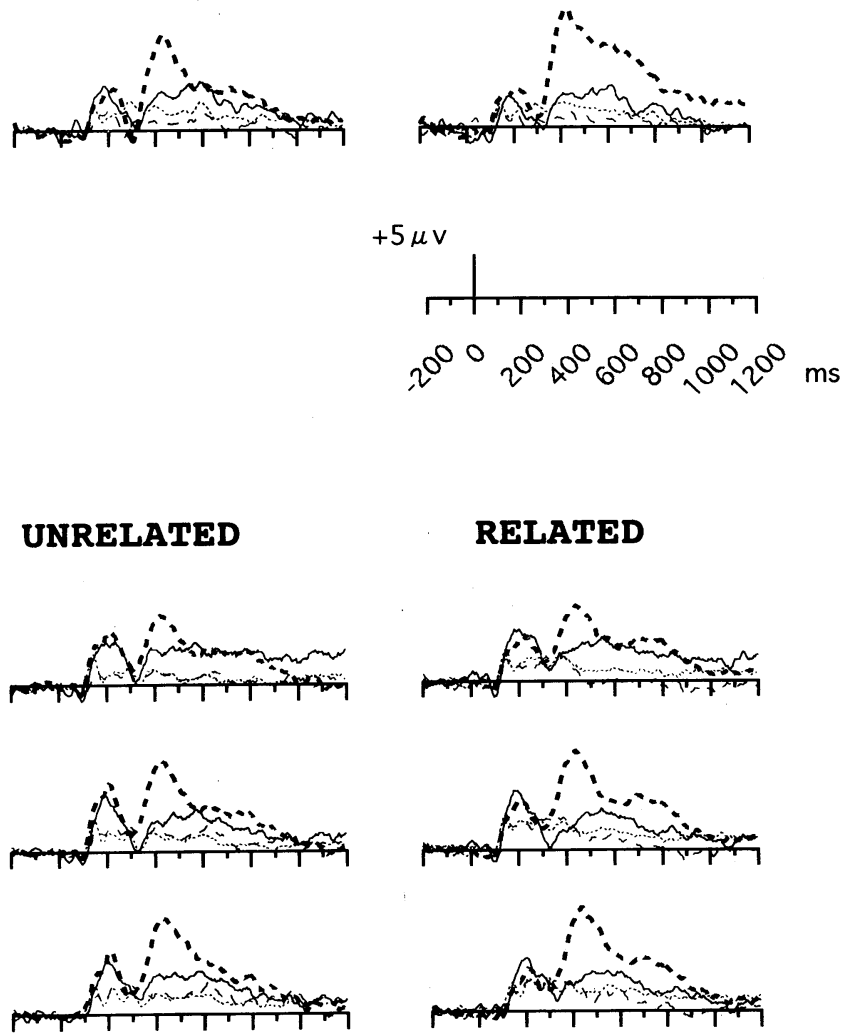

$\mu \mathrm{v}$

\section{RELATED}
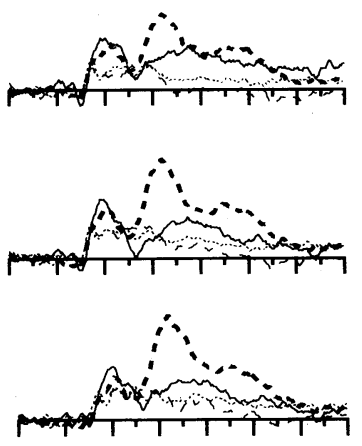

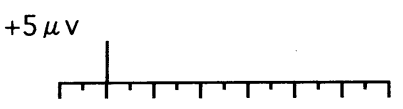

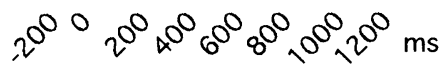

Fig. 1 Grand averaged event-related potentials for the control (left column), semantically-related (center), and unrelated trials (right column) in the two task conditions of semantic matching (upper panel) and non-task (lower panel) at the midline recording sites. The waveforms for Kanji characters at the different serial positions, the first habituation (H1), pretest $(\mathrm{PT})$, test $(\mathrm{T})$, and dishabituation $(\mathrm{D} 1)$, were superimposed. 
F3

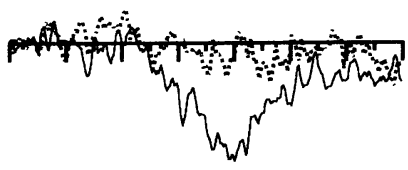

WL

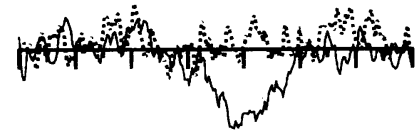

P3

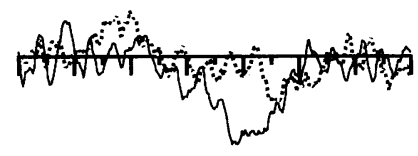

01

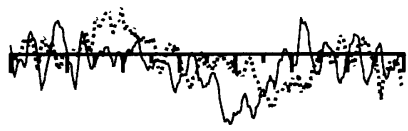

$\mathrm{Fz}$
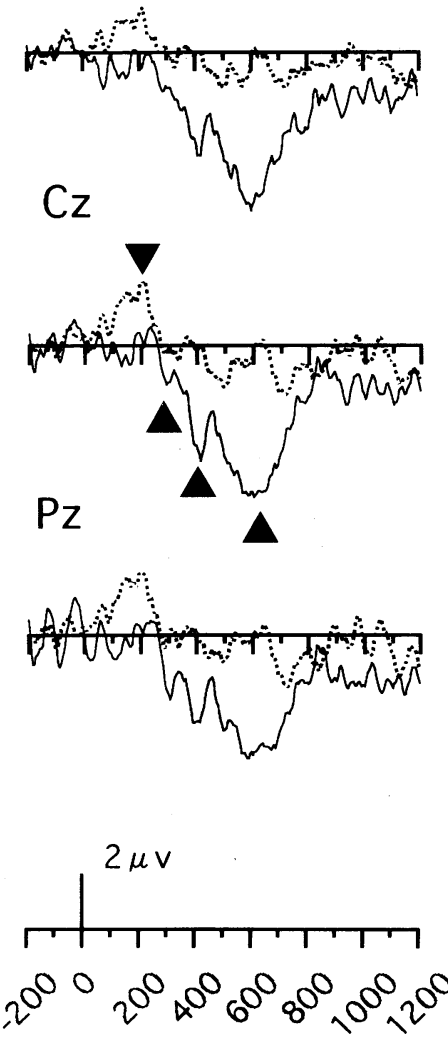

F4
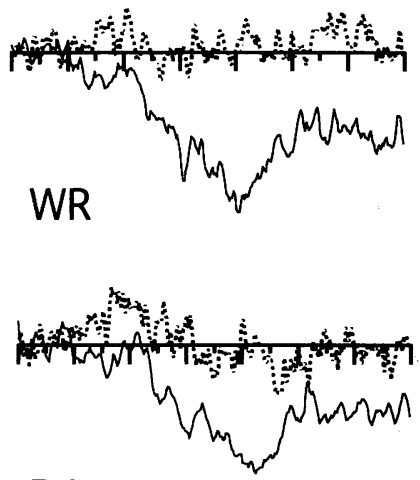

P4

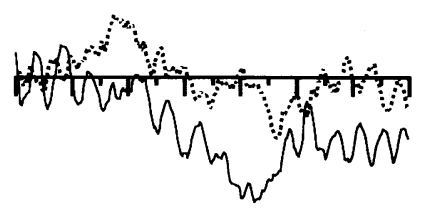

$\mathrm{O} 2$

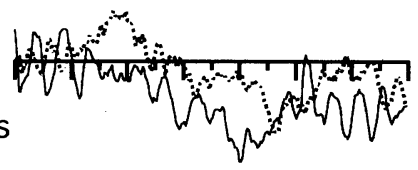

\section{Semantic matching task \\ Non-task}

Fig. 2 Difference waveforms, obtained by subtracting ERPs to test stimuli of semantically related Kanji from unrelated Kanji, at all recording sites. The waveforms for the two task conditions of semantic matching (solid lines) and non-task (dotted lines) were superimposed. Note the positive

$(\boldsymbol{\nabla})$ and negative $(\boldsymbol{\Delta})$ peaks of the difference waveforms.

有意な回復があった。しかし，その回復量に両試 行間で有意な差はなく, 意味関連性（意味プライ

\section{ミング）効果はなかった.}

左右の電極対（F 3-F 4, P 3 -P 4, WL-WR, O 1 -

O 2）別に行った試行 $\times$ 系列位置 $\times$ 電極部位の 3 要因分析では, F 3 -F 4 で試行 $\times$ 位置の交互作用 が有意で $(F(6,66)=3.15, p<.01)$, 下位検定の
結果，正中線上と同様，全試行におけるPT位置 のP200減衰，意味関連と非関連試行のテスト刺 激に対するP200振幅の有意な回復を認めた。ほ かの部位では，有意な主効果および交互作用を認 めなかった。

無課題条件でも，正中線上で試行 $\times$ 位置の交互 作用が有意で $(F(6,66)=5.28, p<.01)$ ， 下位検定 
P200

Semantic matching task Non-task
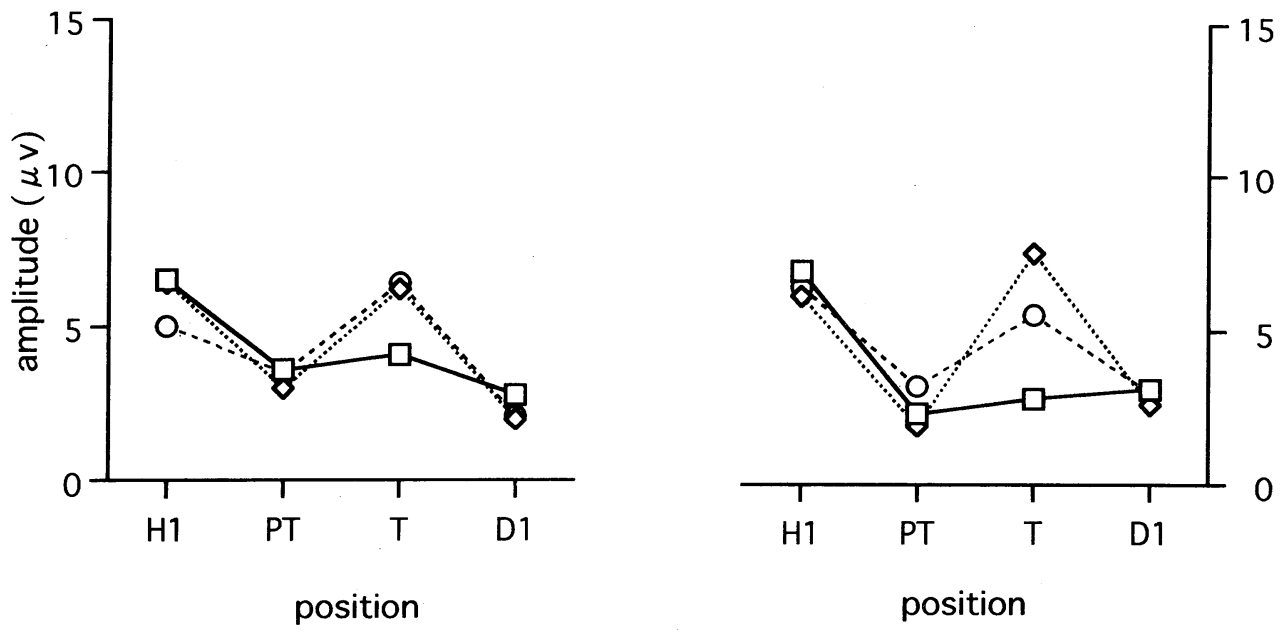

position

N310

Semantic matching task Non-task
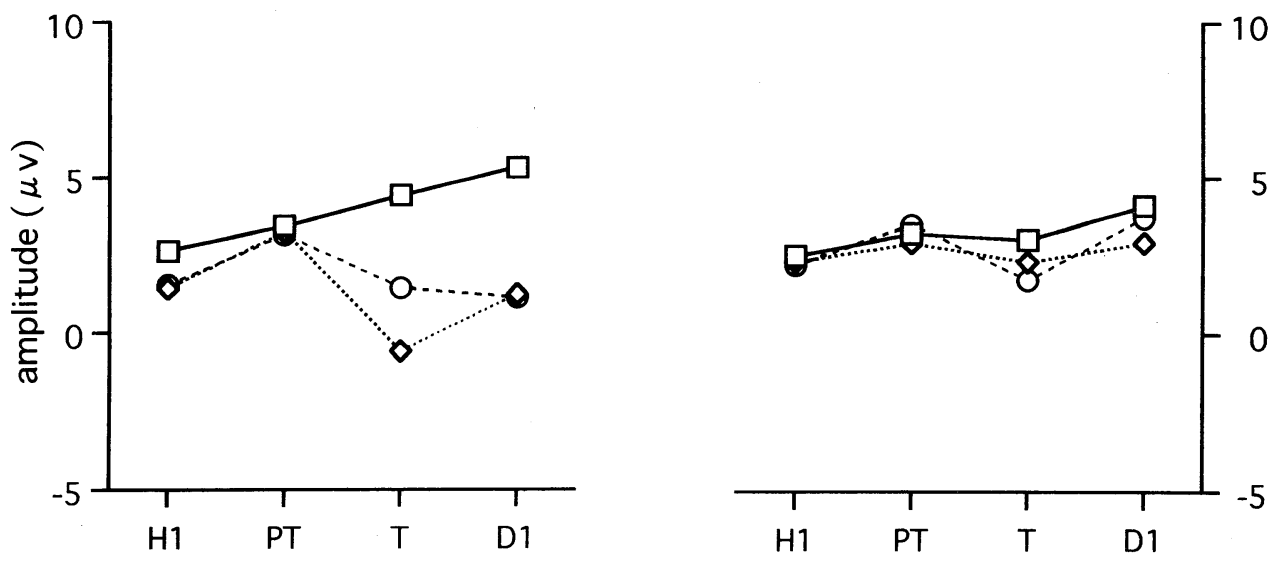

position

position

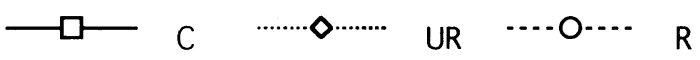

Fig. 3 Mean amplitudes of P200 at Cz (upper panel) and N310 at P4 (lower panel) for the semantic matching task and non-task conditions at positions of $\mathrm{H1}, \mathrm{PT}, \mathrm{T}$, and $\mathrm{Dl}$ in each trail. 
は各試行ともH 1 よりPTのP200減衰, 続くテスト 刺激では意味関連・非関連試行でテスト刺激に対 する回復を認めた。その回復量は意味非関連試行 で大きく，意味プライミング効果を示した。左右 電極部位における分析では, F 3-F 4 においての み，試行×位置の交互作用がみられた $(F(6,66)$ $=4.35, p<.01)$. 下位検定の結果, 正中線上と同様, 全試行でPT位置のP200減衰を示すとともに, テ スト刺激に対する回復量は意味関連試行より意味 非関連試行で有意に大きかった。

\section{N310}

Fig. 3 下段は, 意味判断課題条件と無課題条件 で明瞭な意味関連性減衰を示したP 4 におけるN 310 振幅である。P200と同様の分析を行った結果, 正中線上では, 意味判断課題条件で試行 $\times$ 位置 $\times$ 電極部位の交互作用が有意であった $(F(12,132)$ $=2.81, p<.05)$. 下位検定は, $\mathrm{Cz} \cdot \mathrm{Pz}$ で意味非関 連テスト刺激のN310がPTより有意に大きいこと を示したが，意味関連試行にそうした有意な回復 は見出せず, 意味関連性による相違（意味プライ ミング効果）を認めた。また，Pzにおける意味非 関連テスト刺激のN310は Fzより大きな振幅を示 した.

P 3 -P 4 でも, 意味判断課題条件で 3 要因の交 互作用が有意で $(F(6,66)=3.28, p<.05)$ ，意味関 連と非関連テスト刺激のN310はPTに比べて増大 した。P4では，そのテスト刺激に対する回復量 が意味関連試行より意味非関連試行で大きく, 有 意な意味プライミング効果を示した. F 3 - F 4,

WL-WR, O 1 -O 2 では, 試行 $\times$ 位置の交互作用 が有意であり $(F(6,66)=4.53, p<.01 ; F(6,66)=$ $5.16, p<.01 ; F(6,66)=3.39, p<.05), \mathrm{WL}-\mathrm{WR}$ と 1 -O 2 において, 意味関連・非関連テスト刺激のN 310がPTより大きな陰性電位を示した。

無課題条件では, 有意な効果は見出せなかった。 P400

Fig. 4 上段は意味判断課題と無課題条件でP400 が最大振幅を示すPzに㧍ける平均振幅である。意 味判断課題では, 正中線上において試行 $\times$ 位置の 交互作用が有意であり $(F(3,33)=5.11, p<.01)$, 位置 $\times$ 電極部位の交互作用は有意傾向を示した $(F(6,66)=2.96, p=.06)$. 下位検定は, 意味関連と
非関連テスト刺激に $\mathrm{Cz} \cdot \mathrm{P}$ にに優勢な $\mathrm{P} 400$ が惹起 され, その振幅が意味関連試行で意味非関連試行 より大きいことを認めた。

左右電極対における 3 要因分散分析では， 3 要 因の交互作用がすべての分析でそれぞれ有意また は有意傾向であった $(\mathrm{F} 3-\mathrm{F} 4: F(6,66)=2.78, p<.10$; P3 -P4: $F(6,66)=8.62, p<.01$;WL-WR: $F(6,66)=4.72$, $p<.05 ;$ O 1 -O $2: F(6,66)=2.90, p<.10)$. 下位検定 では, 意味関連と非関連テスト刺激に大きく発達 したP400が, 左側（F 3，WL，P 3，O 1）より 右側 (F 4 - WR・P $4 \cdot \mathrm{O} 2$ ) で大きく, しかも, 意味非関連テス卜刺激より意味関連試行で大きい ことを示した。

無課題条件の正中線上では位置 $\times$ 電極部位の交 互作用を認め $(F(6,66)=8.36, p<.01)$ ，テスト刺 激に惹起された $\mathrm{Cz} \cdot \mathrm{Pz}$ 優勢な $\mathrm{P} 400$ に意味関連性 効果がないことを示した. F 3 -F 4 -WL-WR・P 3-P 4 部位では, テスト刺激に対するP400の発達 を反映して, 位置の主効果のみ有意であった（そ れぞれ, $F(3,33)=7.5, p<.01 ; F(3,33)=9.60, p<.01$; $F(3,33)=9.63, p<.01 ; F(3,33)=5.92, p<.01)$.

\section{N600}

N600は先に波形（特に, Fig. 2 の引算波形）か ら推定した緩徐な陰性電位であり, 意味関連と非 関連テスト刺激に惹起された大きな後期陽性波に 重畳して発達していた。 Fig. 4 下段は明瞭な意味 関連効果が見られたPzにおけるP600振幅である. 分析結果は, 意味判断課題条件の正中線上で試行 ×位置の交互作用があり $(F(3,33)=14.07, p<.01)$, 意味非関連テスト刺激 $\mathrm{N} 600$ が意味関連試行に比 べ，有意に陰性電位を発達させたことを示した。 同様の分析結果は, 左右電極部位でも得られた (F 3 -F $4: F(3,33)=6.54, p<.01$; WL-WR: $F(3,33)=$ $6.86, p<.01$; P 3 -P $4: F(3,33)=9.15, p<.01 ; \mathrm{O} 1-\mathrm{O} 2$ $: F(3,33)=3.48, p<.05)$.

無課題条件では, 有意な効果は見出せなかった。

\section{考察}

本研究の主な目的は, 相互活性化モデルの枠組 みで漢字の読語処理機構を想定し, 表意 (表語) 文字である漢字の形態 (文字・単語) レベルと意 味レベルにおける意味関連応答特性をERPにおけ 
P400

\section{Semantic matching task Non-task}
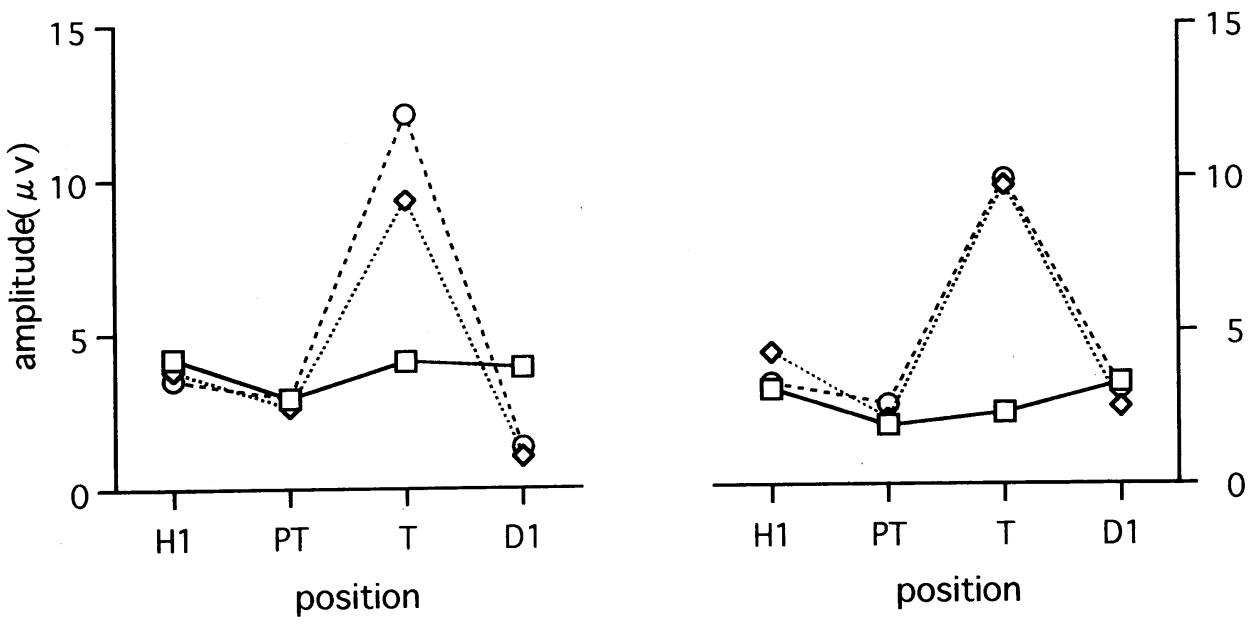

\section{N600}

Semantic matching task

Non-task
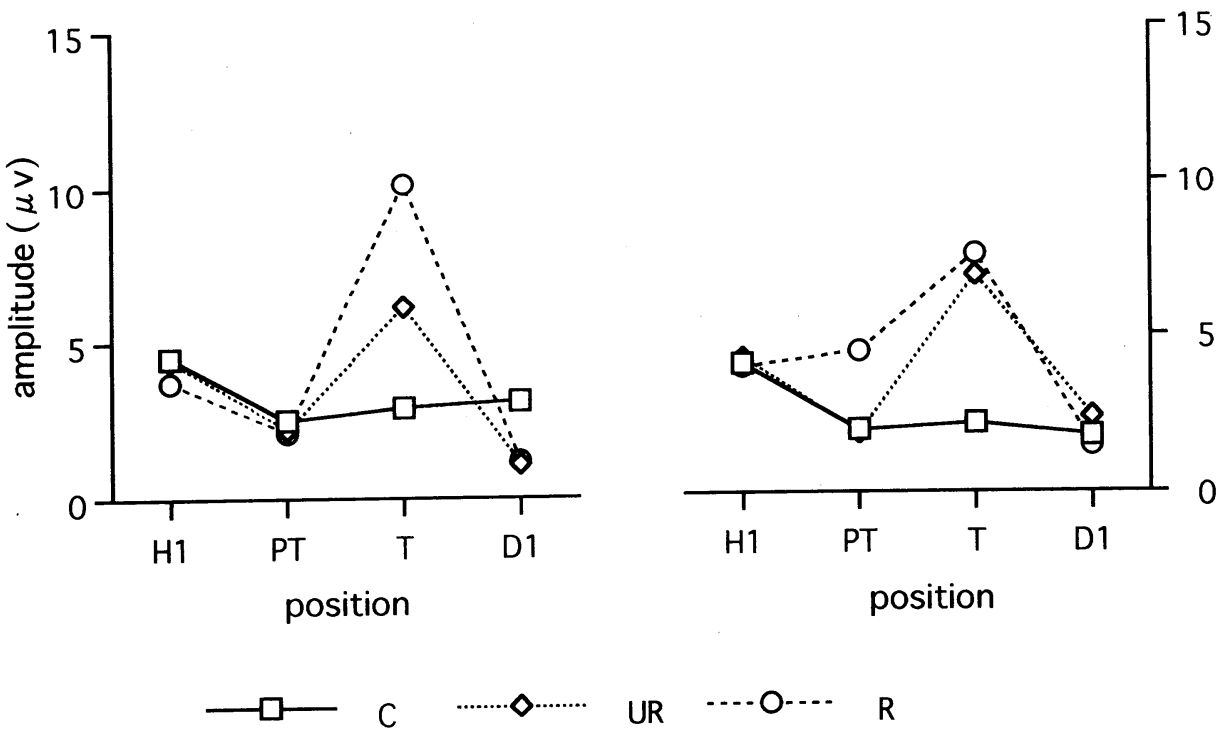

UR $\cdots \cdots O-\cdots \quad R$

Fig. 4 Mean amplitudes of $\mathrm{P} 400$ at $\mathrm{Pz}$ (upper panel) and N600 at Pz (lower panel) for the semantic matching task and nontask conditions at positions of $\mathrm{Hl}, \mathrm{PT}, \mathrm{T}$, and D1 in each trail. 
る意味プライミング効果から探ることであった 意味判断課題と無課題条件の意味関連・非関連テ スト刺激に対するERPには，P200・N310・P400・ N600が観察された。最も短い潜時帯で認めた意 味プライミング効果は, 無課題条件のP200であっ た。しかし，無課題条件では，後続するN $310 ・$ $\mathrm{P} 400 \cdot \mathrm{N} 600$ に効果はなかった。他方, 意味判断 課題における意味プライミング効果はP200にな

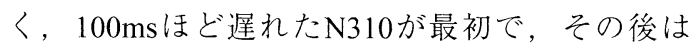
P400・N600にも認めた (Fig. 2 参照).

\section{P200}

本実験で観察されたP200は，Yao \& Morotomi （2000）と一致して，反復刺激に対する減衰（慣 れ現象）およびテスト刺激に対する振幅の回復を 示し, また，その極性・潜時・頭皮上分布からみ て, 序論で述べた従来のP 2 成分に相当する電位 とみなすことができるだろう，P200（P 2）は日 常的に使用する文字・単語 (母語) や熟知度の高 い人の顔などに鋭敏に応答する電位であり，過学 習された生態学的に重要な刺激 (の形態的な変化) に対する初期知覚レベルの注意定位機能にかかわ ると推定されている (Schendan et al., 1998).

このP200における意味プライミング効果は, 意味的な内容にかかわる脳の応答が漢字 (1 文字) 刺激提示開始から $200 \mathrm{~ms}$ 以内に生じたことを示し ている.P2が初期の形態レベルの知覚処理にか かわる電位とすれば（Yao \& Morotomi, 2000; Shimoyama et al., 1992), その意味プライミング効果 は漢字に対する形態（文字・単語）レベルにおけ る意味応答を示唆する。相互活性化モデル（Stolz \& Besner, 1998）に従えば，意味レベルで生じた 意味関連表象の活性化はフィードバック経路を介 して形態レベルの対応する単語（および，文字） 表象を活性化し, 後続の意味関連語入力には形態 レベルの処理効率を高める。無課題条件では，慣 れ刺激（プライム語）によって，そうした意味関 連語の活性化が形態レベルで事前に生じていたた め, 意味関連テスト刺激には非関連刺激と比べ減 弱したP200が観察されたと推定できる。P200が 直接的には初期知覚レベルの注意定位にかかわる 電位とすれば（Schendan et al., 1998），反復刺激 からテスト刺激への変化に対し, 意味関連語には
注意の定位反応が小さかったことを示唆する。す なわち，事前に形態レベルで活性化していると， その表象に対応する入力の形態処理は少ない注意 資源の分配で効率的に実行できることを示してい る.

また，反復刺激に対するP 200 減衰は反復プラ イミング効果とみることができる．上記の意味プ ライミング効果と同様, 反復プライミング効果も 相互活性化モデルの枠組みで捉えると，刺激の初 期知覚レベルの処理が容易になったといえる (Friedrich, Henik, \& Tzelgov, 1991; Stolz \& Besner, 1998）.つまり, 同一刺激の反復提示によって形 態レベルの表象が事前に活性化していたことによ $り$, 注意の定位反応（注意資源の分配）が減少し たため，その注意の定位を反映するP $200 に$ 減衰 が生じたと理解できる。P200において反復刺激 に対する慣れ（H1-PT減衰）とテスト刺激に対す る回復が観察されたが，この反応特徵は従来の定 位反応の特性（Sokolov, 1963）とも一致し，P200 が注意の定位反応に関連する電位という推定に支 持を与える。

本研究で観察されたP200は少なくとも二つの 下位成分に分けられるかもしれない，顔刺激を用 いた研究ではあるが, P 2（P200）の下位成分を 示唆する報告によれば（Watanabe et al., 1999）， 一つは鼻尖を基準に側頭葉後下部（T 5, T 6 ）か ら記録されるN200である（Allison et al., 1994a, 1994b).もう一つは両耳㭼結合を基準として Cz からやや遅れて記録されるVPP (Jeffreys, 1989)

である、本研究では, 両耳染結合を基準としてい たため,こうしたP200の可能な二つの下位成分 を分離して観察できなかった。今後の課題として, 本研究におけるP200成分の発生源などについて さらに探る必要がある。

\section{N310}

意味判断課題条件でテスト刺激に惹起された $\mathrm{N}$ 310 は, 従来の多くの N400研究（たとえば, Bentin, McCarthy, \& Wood, 1985) と類似して, 意味プライミングに伴う減衰を示した。また， N 310は中心-頭頂優位で右頭頂・後頭部に偏側分布 し, この頭皮上電位分布も従来の多くの研究が報 告する N400分布（たとえば, Silva-Pereyra, Har- 
mony, Billanueva, Fernandez, Rodriguez, Galan, Diaz-Comas, Bernal, Fernandez-Bouzas, Marosi, \& Reyes, 1999; Holcomb, 1988; Kutas \& Van Petten, 1988; Curran, Tucker, Kutas, Posner, 1993; Katayama, Miyata, \& Yagi, 1987) と一致する. 従って, 本研究で得られたN310は従来のN400成分に相当 するものといえるだろう。通常のN400成分より 潜時が短い点は，意味レベルに至る処理時間の短 縮を示すようである。短縮の理由は, テスト刺激 に先行して同じ文字が反復提示されるという慣れ パラダイムの特性, 表意 (語) 文字で複数の下位 音韻成分に分かれることができないという漢字の 特性, 刺激として漢字 1 文字ずつ提示された点な どがあげられる。

N310（N400）における意味プライミング効果 は，相互活性化モデルに対応づけると，意味レベ ルにおける意味関連表象の活性化で説明できる。 先行する慣れ刺激によって生じた意味レベルの事 前の活性化は意味関連入力の処理負荷を軽減させ, その結果，意味処理の負荷を反映するN 310 （N400）の発達が減少したと理解できる.

\section{$\mathrm{P} 400 \cdot \mathrm{N} 600$}

意味判断課題条件では，N310に続き，P400と N 600に意味プライミング効果が観察された。P400 は，極性，中心-頭頂部優勢に分布する点，低頻 度提示刺激に応ずる点などから, 従来のP3b成分 に相当する電位であろう。P3b振幅は課題の難易 度に応じて増減することが知られている (Pritchard, 1981)。従って，意味関連テスト刺激 に対するP400（P3b）増強は, 意味非関連試行と 比べて, 意味関連試行では課題遂行に要請された 意味判断が容易であったことを示している.

意味判断課題遂行時には，さらに，N600で意 味プライミング効果が観察された。N600は,

P400（P3b）頂点から基線復帰過程で，意味非関 連テスト刺激に特異に観察された緩徐な陰性波で ある. 統計学的に有意な効果は得られなかったが, Fig. 2 の波形では, 正中線上の前頭・中心部と右 側, 特に, 前頭部（F4）で大きく発達している. 右前頭葉から右頭頂葉の活動は標的探索時などに 働く注意 (覚醒, alertness) 制御系との関連が示 唆されているが (Posner \& Raichle, 1994), N600
はそうした注意機構にかかわる電位かもしれない。 意味非関連試行では，一旦，刺激評価（意味判断） を行った後も，先行刺激で示されたカテゴリー内 項目との関連を探る確認が必要であり，その作業 を支えるために注意制御系の働きを N600は反映 しているようにみえる。

無課題条件では，意味プライミング効果はみら れなかったものの，テスト刺激に対しP400が惹 起された。意味判断課題と類似して，中心-頭頂 部に優勢な分布を示したが，意味関連性でP400 振幅に違いはなかった. Polich（1989a）によれば, 本条件のように積極的に課題を遂行しないような 受動的な状況でも, 并別容易な低頻度提示刺激に は，P3bとほぼ同様の陽性電位が出現する。実験 後の内省で, 被験者は提示される漢字を黙読し, テスト刺激として提示された漢字の変化，さらに は，慣れ刺激とテスト刺激の意味的関連性にも気 ついていたと報告している。こうした内省報告に $\mathrm{P} 400$ の出現は一致する.

\section{漢字読語処理における課題の影響と意味応答レベ ル}

意味判断課題と無課題条件で明らかに潜時の異 なるERP成分で意味プライミング効果が観察され た。無課題時には形態レベルにおける意味応答を 示すP200減衰, 意味判断課題では最初のプライ ミング効果として意味レベルを反映する N310減 衰が生じた。意味判断課題では, さらにその後, 課題遂行の難易度に応ずるP 400 , 意思決定内容 の確認作業と関連するとみられるN600にも，意 味プライミング効果が認められた。 そこには，漢 字読語処理における明瞭な課題の影響がある.

P200に意味プライミング効果が得られた無課 題条件では, 特定の刺激に反応するような課題遂 行は要請されなかった。 上記の内省報告（および テスト刺激に対するP400の惹起) からもわかる ように, 被験者は提示される文字を黙読する状況 であった。この知見を相互活性化モデル（Stolz＆ Besner, 1996, 1998）の枠組みで捉えると，実験的 な課題の制約がないような条件下では, 先行文脈 に導かれて，意味レベルから形態レベル（文字・ 単語) への活性化フィードバックによって, 潜在 的に初期知覚処理が効率的に実行され, 高次な意 
味レベルの処理負担を軽減するようにみえる。

意味判断課題条件では, 反復提示される慣れ刺 激とテスト刺激との意味関連性判断が要請され， ボタン押し反応によって応答する必要があった。 意味レベルのプライミング効果を示す知見から， 誤りなく効率的に課題を遂行する被験者の方略が 推定できる. 意味レベルからの事前の活性化フィー ドバックを受け，形態レベルで意味関連テスト刺 激の表象に高い活性化が生じたとしても，その活 性度の違いをもって意味関連性判断を行うのは, 誤反応を避ける意味で危険度が高い。そうした判 断は，短期記憶探索のファジー痕跡モデル (Cooney \& Troyer, 1994) にみられるように, 形 態レベルの感覚的な字面（verbatim）に基づく 「この系列で見た感じ」といった評価（familiarity evaluation）に似ている。正確に課題を遂行する には，形態レベルでは文字变化の検出にとどめ, 意味レベルでの判断が要請される。この意味レベ ルにおける判断の促進に, プライミング形成（先 行刺激による意味関連語の活性化) は役割を果た したのであろう。

こうした課題内容に応じたプライミング・レベ ルの移動は，すでに述べたように，相互活性化モ デルに基づくStolz \& Besner（1996，1998）が報告 しており，それに呼応するものである。また，読 語処理に応ずるERP成分の課題依存性は, Bentin,

Mouchetant-Rostaing, Giard, Echallier, \& Pernier （1999）に一致する。これらの知見はいずれも読 語処理活動に及ぼす高次機能からの制御の強さを 示している。

\section{まとめ}

本研究では, 相互活性化モデルの枠組みで漢字 の読語処理機構を想定し, 表意 (表語) 文字であ る漢字の形態 (文字・単語) レベルと意味レベル における意味関連応答特性をERPにおける意味プ ライミング効果から探ってみた。その結果，（1） 無課題条件では, 形態レベルの意味関連応答を示 すP200（P2）減衰，（2）意味判断課題では, 意 味レベルのプライミング効果を示す N310（N 400）減衰が観察された。こうした知見から，（1） 通常の黙読時には, 少なくとも漢字については,
先行文脈に応じて形態レベルで読語処理を促進す る意味関連応答があること, (2) そうした意味 関連応答は課題依存性が高く，それを支える活性 化拡散に制御性があり，その時々の意図（万略） に応じて形態レベルと意味レベルの間で移動する こと, この 2 点を示唆した. 今後, 漢字の形態レ ベルの意味応答特性をさらに明らかにするため, かな文字表記の単語などとの比較が望まれる。

\section{引用文献}

Allison, T., Ginter, H., McCarthy, G., Nobre, A., Puce, A., Ludy, M., \& Spencer, D. D. 1994a Face recognition in the human extrastriate cortex. Journal of Neurophysiology, 71, 821-825.

Allison, T., McCarthy, G., Nobre, A., Puce, A., \& Belger, A. 1994b Human extrastriate visual cortex and the perception of faces, words, numbers, and colors. Cerebral Cortex, 5 , 544-554.

Anderson, J. R. 1976 Language, memory, and thought. Hillsdale, NJ: Erlbaum.

Anderson, J. R. 1983 The architecture of cognition. Cambridge, MA: Harvard University Press.

Bentin, S., McCarthy, G., \& Wood, C. C. 1985 Eventrelated potentials, lexical decision, and semantic priming. Electroencephalography and Clinical Neurophysiology, 60, 343-355.

Bentin, S., Mouchetant-Rostaing, Y., Fiard, M. H., Echallier, J. F., \& Pernier, J. 1999 ERP manifestations of processing printed words at different psycholinguistic levels: time course and scalp distribution. Journal of Cognitive Neuroscience, 11, 235-260.

Collins, A. M., \& Loftus, E. F. 1975 A spreading-activation theory of semantic processing. Psychological Review, 82, 407-428.

Cooney, J. B., \& Troyer, R. 1994 A dynamic model of reaction time in a short-term memory task. Journal of Experimental Child Psychology, 58, 200-226.

Curran, T., Tucker, D., Kutas, M., \& Posner, M. I. 1993 Topography of N400: brain electrical activity reflecting semantic expectancy. Electroencephalograph and Clinical Neurophysiology, 88, 188-209.

Feldman, L. B., \& Turvey, M. T. 1980 Words written in Kana are named faster than the same words written in Kanji. Language and Speech, 23, 141-147.

Friedrich, F. J., Henik, A., \& Tzelgov J. 1991 Automatic process in lexical access and spreading activation. Journal of Experimental Psychology: Human Perception and Performance, 17, 792-806.

御領 謙 1987 読むということ 東京大学出版会

Holcomb P. 1988 Automatic and attentional processing: an event-related brain potential analysis of semantic priming. Brain and Language, 35, 66-85. 
Jeffreys, D. A. 1989 A face-responsive potential recorded from the human scalp. Experimental Brain Research, 78, 193-202.

Katayama, J., Miyata, Y., \& Yagi, A. 1987 Sentence verification and event-related brain potentials. Biological Psychology, 25, 173-185.

Kimura, Y. 1984 Concurrent vocal interference: Its effects on Kana and Kanji. Quarterly Journal of Experiment Psychology, 36A, 117-131.

Kutas, M., \& Hillyard, S. A. 1980 Reading senseless sentences: brain potentials reflect semantic incongruity. Science, 207, 203-205.

Kutas, M., \& Van Petten. C. 1988 Event-related brain potentials studies of language. In Ankles, Pk., Jennings, JR., Coles, MGH (Eds.), Advances in psychophysiology. Greenwich, CT: JAI press. Pp. 139-187.

McClelland, J. L. 1987 The case for interactionism in language processing. In M. Coltheart (Eds.), Attention and performanceXII. London: Lawrence Erlbaum Associates.

McClelland, J. L., \& Rumelhart, D. E. 1981 An interactive activation model of context effects in letter perception: Part 1. An account of basic findings. Psychological Review, 88, 375-407.

Meyer, D. E., \& Schvaneveldt, R. W. 1971 Facilitation in recognizing pairs of words: Evidence of a dependence between retrieval operations. Journal of Experimental Psychology, 90, 227-234.

Morton, J. 1964 The effects of context on visual duration thresholds for words. British Journal of Psychology, 55, 165-180.

Morton, J. 1969 Interaction of information in word recognition. Psychological Review, 76, 165-178.

Neely, J. H. 1977 Semantic priming and retrieval from lexical memory: Roles of inhibitionless spreading activation and limited-capacity attention. Journal of Experimental Psychology: General, 106, 226-254.

Neely, J. H. 1991 Semantic priming effects in visual word recognition: A selective review of current findings and theories. In D. Besner \& G. Humphreys (Eds.), Basic processes in reading: Visual word recognition. Hillsdale, NJ: Erlbaum. Pp. 264-336.

小川嗣夫 1972 52カテゴリに属する語の出現頻度表 人文論究 (関西学院大学文学部紀要), 22, 1-68.

Polich, J. 1989a P300 from a passive auditory paradigm. Electroencephalography and Clinical Neurophysiology, 74, 312-320.

Posner, M. I., \& Raichle, M. E. 1994 Images of Mind. New York: Sientific American Library.

Pritchard, W. S. 1981 Psyochophysiology of P300. Psychological Bulletin, 89, 506-540.
Rumelhart, D. E., \& McClelland, J. L. 1982 An interactive activation model of context effects in letter perception: Part 2. Psychological Review, 89, 60-94.

Sasanuma, S. 1975 Kana and Kanji processing in Japanese aphasics. Brain and Language, 9, 298-306.

Schendan, H. E., Ganis G., \& Kutas M. 1998 Neurophysiological evidence for visual perceptual categorization of words and faces within $150 \mathrm{~ms}$. Psychophysiology, 35, 240-251.

Shimamura, A. 1987 Word comprehension and naming: An analysis of English and Japanese orthographies. American Journal of Psychology, 100, 15-40.

Shimoyama, I., Morita, Y., Uemura, K., Kojima, Y., Nakamura, T., Nishizawa, S., Yokoyama, T., Ryu, H., Murayama, M., \& Uchizono, K. 1992 Verbal versus nonverbal visual evoked potentials: Kanji versus line drawings. Brain Topography, 5, 35-39.

Silva-Pereyra, J., Harmony, T., Billanueva, G., Fernandez, T., Rodriguez, M., Galan, L., Diaz-Comas, L., Bernal, J., Fernandez-Bouzas, A., Marosi, E., \& Reyes, A. 1999 N400 and lexical decisions: automatic or controlled processing? Clinical Neurophysiology, 110, 813-824.

Sokolov, E. N. 1963 Perception and the conditioned reflex. Oxford: Pergamon Press.

Stolz, J. A., \& Besner, D. 1996 The role of set in visual word recognition: Activation and activation blocking as nonautomatic processes. Journal of Experimental Psychology: Human Perception and Performance, 22, 11661177.

Stolz, J. A., \& Besner, D. 1998 Levels of representation in visual word recognition: A dissociation between morphological and semantic processing. Journal of Experimental Psychology: Human Perception and Performance, 24, 1642-1655.

Taft, M. 1991 Reading and the mental lexicon. Lawrence Erlbaum Associates Limited.

Watanabe, S., Kakigi R., Koyama, S., \& Kirino, E. 1999 Human face perception traced by magneto-and electroencephalography. Cognitive Brain Research, 8, 125-142.

Wydell, N. T., Patterson K. E. \& Humphreys, G. W. 1993 Phonologically mediated access to meaning for Kanji: Is a Rows still a Rose in Japanese Kanji? Journal of Experimental Psychology: Learning, Memory, and Cognition, 19, 491-514.

Yao, P., \& Morotomi, T. 2000 ERP correlates to initial perceptual processing of native and foreign language characters in a habituation paradigm. Japanese Journal of Physiological Psychology and Psychophysiology, 18, 4552. 
付録 本研究に扔ける漢字刺激

\begin{tabular}{|c|c|c|c|c|c|}
\hline \multicolumn{2}{|c|}{ 意味関連試行 } & \multicolumn{2}{|c|}{ 意味非関連試行 } & \multicolumn{2}{|c|}{ 統制試行 } \\
\hline 慣れ刺激 & テスト刺激 & 慣れ刺激 & テスト刺激 & 慣れ刺激 & テスト刺激 \\
\hline 肺 & 胃 & 船 & 瓜 & 党 & 党 \\
\hline 桃 & 梨 & 鴉 & 芋 & 席 & 席 \\
\hline 母 & 父 & 月 & 数 & 街 & 街 \\
\hline 踏 & 蹴 & 戸 & 咳 & 飴 & 飴 \\
\hline 紙 & 筆 & 毛 & 万 & 酢 & 酢 \\
\hline 裏 & 表 & 笑 & 車 & 豊 & 豊 \\
\hline 前 & 後 & 耳 & 逃 & 酒 & 酒 \\
\hline 上 & 下 & 豆 & 水 & 桜 & 桜 \\
\hline 語 & 文 & 刻 & 道 & 冬 & 冬 \\
\hline 熊 & 虎 & 班 & 庭 & 消 & 消 \\
\hline 鮭 & 鯛 & 酸 & 具 & 塩 & 塩 \\
\hline 手 & 足 & 飲 & 影 & 週 & 週 \\
\hline 海 & 湖 & 角 & 塔 & 来 & 来 \\
\hline 種 & 実 & 金 & 蚁 & 待 & 待 \\
\hline 錠 & 粒 & 菊 & 門 & 芽 & 芽 \\
\hline 松 & 竹 & 首 & 板 & 男 & 男 \\
\hline 叫 & 吠 & 鼻 & 運 & 線 & 線 \\
\hline 悲 & 喜 & 寝 & 株 & 税 & 税 \\
\hline 短 & 長 & 狐 & 界 & 点 & 点 \\
\hline 冊 & 枚 & 見 & 音 & 唄 & 唄 \\
\hline 英 & 日 & 国 & 響 & 印 & 印 \\
\hline 欧 & 打 & 雨 & 徵 & 栄 & 栄 \\
\hline 妻 & 夫 & 店 & 赤 & 読 & 読 \\
\hline 麦 & 米 & 血 & 穴 & 君 & 君 \\
\hline 走 & 歩 & 岩 & 間 & 駅 & 駅 \\
\hline 賢 & 愚 & 病 & 傘 & 朝 & 朝 \\
\hline 春 & 夏 & 煮 & 禪 & 雄 & 雄 \\
\hline 東 & 南 & 串 & 他 & 夜 & 夜 \\
\hline
\end{tabular}

